\title{
Elite Addicts?
}

The gradually increasing demands of élite sport have created a small cadre of highly trained and specialized athletes, professional in all but name. The training necessary at Olympic level is such that virtually total dedication of lifestyle and time is required even to reach the levels from which final selection is made. Clearly, such commitment must compromise other achievement in the élite athlete's career and personal life. While it would quite recently have been considered a good idea to do some sport - and to train a bit more if success indicated major talent, it may now be reasonable to question why such levels of self-sacrifice have become necessary, what personality traits this may indicate and whether, or how often, 'success' in sport is worth its price.

What is 'sport'? The Corinthian concept is clear and implies recreation, fun and the pursuit of mental and physical well-being. Achievement is, by definition, as limited as the limited commitment given to a hobby as opposed to work. Financial reward is, of course, contradictory to this approach. This attitude has been associated with 'undemocratic' social behaviour, such as the disqualification from sport of artisans because they 'worked'. Social changes widening the base of sports participation inevitably eroded the Corinthian attitude, though its proponents have fought a long and bitter rearguard action well seen, for instance, in the behaviour of several of the sport governing bodies.

The conundrum remains - 'if play becomes work, what becomes play?' It is clear that élite sport is now 'work' rather than 'play' and that élite sport is a different concept from recreational sport, including the universal Sport for All idea of exercise for a healthy life (for the masses).

As professional sport became a 'way up from the ghetto' there was an inversion of earlier social discrimination, 'Gentlemen' did not play for money. Later, when the International Olympic Committee sold out its founding philosophy, so that an 'amateur' is now someone who can compete for limitless reward as long as his governing body takes a cut, its could plead that its prostitution of sport truly reflected ambiguities in society's attitudes. Britain's traditional ambivalence towards public funding and its sporting champions sharpens the dilemma for talented individuals who have, in effect, to choose between opting out of maximum commitment or selling themselves to sponsors for the necessary financial sustenance. Sadly, history suggests that professionalism's seduction of sport from joyous outlet to sponsored public spectacle may be symptomatic of the terminal decline of its host society.

Roger Hackney's 'Challenge of élite training' on our correspondence page, raises the interesting suggestion that exercise addiction is an adaptive mechanism which élite athletes develop in response to the severe demands of today's training. This might contradict the notion that élite athletes are those whose unusual exercise compulsion is strong enough to drive them towards maximum physical development regardless of other sacrifice involved. Is a compulsion to exercise a potentially severe symptom which can impede the athlete's mental health? Does this addiction need the same clinical help as the others? Clinicians are familiar with exercise compulsion in high-training low achievers but the notion that exercise compulsion may be a sine qua non of élite sporting achievement has serious implications for our provision of medical care - not only for the élite but for sport more generally. The tendency for training and performance standards relentlessly to rise implies that clinical problems at this level will increase. Observation of gradually increasing stress reactions and mental ill-health in élite performers and, incidentally, their attendants implies that we should now be laying down a secure and accepted framework for the provision of psychological and psychiatric care for our top sportsmen and women.

That there is still much to do in persuading the sport governing bodies of the importance of this development can be seen in the current hostility or indifference of many to such ideas and their historical reluctance responsibly to promote, let alone fund, adequate infrastructure provision in their sports. 